Brit. J. industr. Med., 1963, 20, 145.

\title{
EFFECT OF RADIOGRAPHIC TECHNIQUE ON READINGS OF CATEGORIES OF SIMPLE PNEUMOCONIOSIS
}

\author{
BY \\ M. E. WISE* and P. D. OLDHAM \\ From the Department of Social Medicine, Oxford University, and the Pneumoconiosis \\ Research Unit, Llandough Hospital, Penarth, Glamorgan
}

(RECEIVED FOR PUBLICATION APRIL 5, 1962)

\begin{abstract}
Two chest radiographs of each of 687 coal-face workers, obtained during two surveys two and a half years apart at eight pits in South Wales, have been assessed according to their technical quality as "acceptable", "black", "grey", or "white". The effect of variations in quality on the reading of the category of simple pneumoconiosis (independently carried out) is reported; the effect on change of category between the two surveys is considerable.

From the distributions of categories in each class of technical quality within a pit on each survey, it appears that the extreme categories $\mathbf{0}$ and 3 are read proportionately more often on acceptable films than on imperfect films. This phenomenon is described quantitatively by fitting a continuous distribution of abnormality to each of the sub-groups, and transforming the $x$-ray continuum scale into a scale that approximately normalizes the distributions. Measured in this way, the black films are found to have more than twice as much effect on the reading as the grey and white films. A method for approximately correcting for this effect is given.

The findings are interpreted in terms of random observer error in assessing abnormality on a continuous scale, and a recently published model for observer error is criticized.
\end{abstract}

Readers of $x$-ray films have long appreciated that their interpretations are likely to be affected by the radiographic technique used, even within a range of film quality which would generally be quite acceptable. In pneumoconiosis, Fletcher and Oldham (1949) showed that "soft", underpenetrated films were read as showing too much abnormality, while the opposite was true of "hard", overpenetrated films. Since then readers have generally attempted to make allowances for these tendencies, but it is not known how well they succeed. The most common assumption is that the effect of bad technique will be either to increase the random observer error, or to introduce systematic bias over a short run of films. Since bad technique is remedied when it is observed, such biases will, in the long run, have the effect of contributing more random error.

\section{Classification of Films According to Technical Quality}

Two radiological surveys of the men in a set of eight pits have been used in an analysis of the pro-

*Present address: University Physiology Laboratory, Leiden, Holland. gression of simple pneumoconiosis (Wise and Oldham, 1963). The quality of each film from these surveys, save for two pairs which were not available, was assessed independently of the amount of abnormality by an experienced radiographer and a physician interested in the standardization of technique. The films were assessed as "acceptable" (C), "slightly or definitely black" $\left(\mathrm{B}_{1}\right.$ and $\left.\mathrm{B}_{2}\right)$, "grey" $\left(G_{1}\right.$ and $\left.G_{2}\right)$, and "white" $\left(W_{1}\right.$ and $\left.W_{2}\right)$. This system of classification, rather than one based on the cause underlying the technical defect, was deliberately adopted for the sake of objectivity. Without additional knowledge, it is in general impossible to be sure if, for example, a "grey" film is the result of fading of the latent image, faulty development, or excessive scatter from obese tissue. Two independent readings were made, and the two readings agreed in about $90 \%$ of the cases. In all the remaining cases an agreed assessment was reached by discussion.

It is obvious that the amounts of blackness, greyness, and whiteness do not vary in steps. For the same reasons as those advanced in the case of simple pneumoconiosis an analysis that allows for this will 
TABLE 1

EFFECT OF TECHNIQUE ON CATEGORIES OF SINGLE FILMS; BOTH SYSTEMS OF READING Observed frequencies (upper rows) compared with those expected if techniques and categories were independent

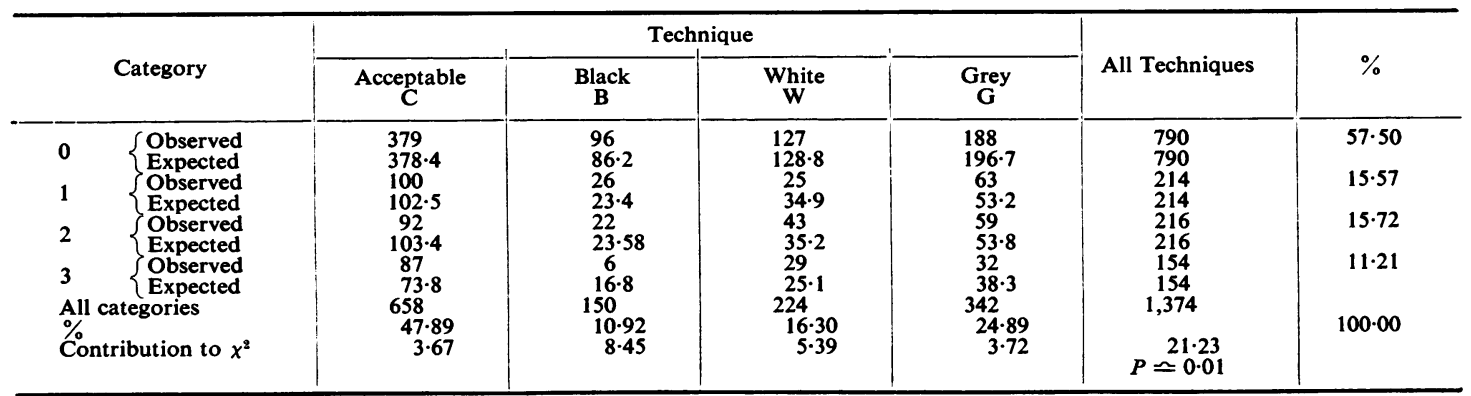

make better use of the material, although there are qualitative as well as quantitative differences present, and it is improbable that "grey" falls on a continuum between "black" and "white" in these circumstances. Liddell (1961) has introduced into his analysis of the effects of film technique a number of gradings of film quality forming an ordered sequence, and with some success.

In our analysis we have not been able to distinguish between the effects of "slight" and "definite", either of blackness, greyness, or whiteness, but the proportion of films in the "definite" classes was very small.

\section{Effect of Film Technique in Single Readings}

The simplest comparison to make is in the distribution of film categories read in the different kinds of films. Table 1 gives the overall distribution of category readings for acceptable, black, grey, and white films, compared with the number expected if the film quality has no effect on the reading. There are, in fact, large deviations; these mainly appear in the black films, for which too few category 3's were read, and to a lesser extent in the white films, with too few category 1's and too many category 2's and 3's.

This was a little unexpected as the readers themselves found it most difficult to read grey films. As only $11 \%$ of the films were black one might expect that the effect of variations in technique should not be too serious.

Effect of Combinations of Film Technique on 1st and 2nd Survey Readings for the Same Man in relation to Radiological Progression

In view of the results of this first analysis, those shown in Tables 2, 3, and 4 (provided by Professor A. L. Cochrane) were all the more unexpected and disturbing. These show the percentages of various combinations of film readings for all 16 possible combinations of film technique for the first and second survey films of the same men. The comparison is made both for separate and for side-byside readings.

Separate tables are given for progression from categories 0,1 , and 2. The last row in each part of each table gives the number of men increasing their category, less the number decreasing their category, as a percentage of all pairs with the same first category. The general pattern is the same by both methods of reading. The proportion seems to depend more on the first film than on the second; in particular it is high when the first film is black or grey and the second one not black, and it is low when the first film is white.

There is less variation in the percentages changing their categories when the films are read side by side; we have previously pointed out (Wise and Oldham, 1963) that most of these percentages are smaller. Also, the combinations involving bad films differ more from the corresponding ones for separate readings than do those for good films. This is consistent with the idea that there is less random error but some bias when the films are read side by side.

In any case, it is clear that some correction must be made when estimating progression, especially as this must for the present be estimated from separate readings (Wise and Oldham, 1963). Table 4, which gives the percentage of men changing their category according to the separate readings, shows that with several combinations of technique this percentage is about doubled compared with that for good films.

Effect of Film Technique on Groups of Readings of Comparable Populations.-One factor has not yet been brought into the analysis. The distribution of abnormality is certainly different in the different pits, 
TABLE 2

FILMS READ SEPARATELY FOR SIMPLE PNEUMOCONIOSIS ANALYSED BY TECHNIQUE AND ORIGINAL $X$-RAY CATEGORY

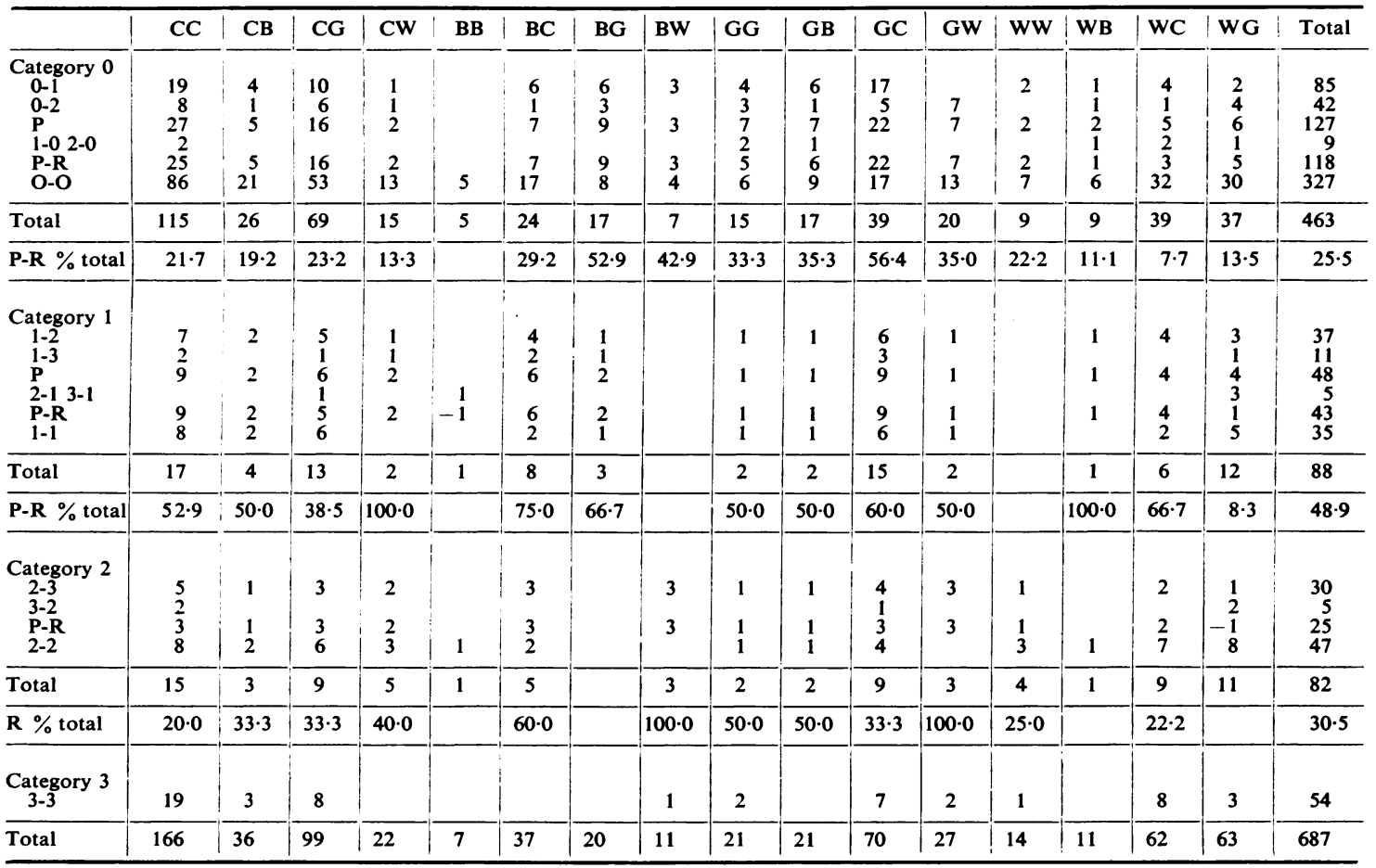

C acceptable, B black, $\mathbf{G}$ grey, $W$ white, $P$ increase of category, $R$ decrease of category

and the different kinds of films were also distributed very unevenly among the pits. For this kind of study the ideal situation would have been to have various kinds of bad film distributed about equally among the pits for each survey. As it is, the excess of high category readings on white films could arise simply because there really is more abnormality in the pits where there were many white films (in particular in the second survey of pit $F$ and the first survey of pit $\mathbf{H})$. It is then essential to make what comparisons we can for each survey within one pit.

This kind of comparison could still mislead if there were a series of unlucky coincidences; for example men with category 3 pneumoconiosis might come up together during a run of films with the same kind of poor technique. In what follows we shall assume that this had not occurred. The withinpit and survey comparisons are given in Table 5. For each kind of film, acceptable, black, grey, and white, the distribution of 0's, 1's, 2's, and 3's is given in the rows in percentages.

If film technique has no influence on the category being read, the percentages reading down each column should be about the same, apart from random fluctuations. These are smallest, of course, in the larger sub-groups, and these column percentages vary much less than the previous analysis might suggest. The most noticeable feature is that the extreme categories, 0 and 3 , tend to occur more often in the distributions for good films than in those for black, grey, and white films.

In order to make some allowance for this effect, it must be described quantitatively. In the next section we shall see that although it is impracticable to correct a single category reading for technique, we can do so for a whole distribution for a subgroup of black, grey, or white films.

\section{Smooth Curves Fitted to Distributions of Categories Read on Good, Black, Grey, and White Films}

It is well known (e.g. Kendall and Stuart, 1958) that any continuous distribution can by a suitable transformation of the unit of measurement be transformed to any other. The transformation given by Wise and Oldham (1963) (appendix A) turns all the distributions of $x$-ray categories of simple 
TABLE 3

FILMS READ TOGETHER FOR SIMPLE PNEUMOCONIOSIS ANALYSED BY TECHNIQUE AND ORIGINAL $X$-RAY CATEGORY

\begin{tabular}{|c|c|c|c|c|c|c|c|c|c|c|c|c|c|c|c|c|c|}
\hline & $\mathrm{CC}$ & CB & CG & $\mathrm{CW}$ & BB & BC & BG & BW & GG & GB & GC & GW & Ww & WB & wc & WG & Total \\
\hline $\begin{array}{c}\text { Category } 0 \\
0-1 \\
0-2 \\
\mathbf{P} \\
0-0\end{array}$ & $\begin{array}{l}22 \\
1 \\
23 \\
86\end{array}$ & $\begin{array}{r}1 \\
1 \\
22\end{array}$ & $\begin{array}{r}14 \\
1 \\
15 \\
51\end{array}$ & $\begin{array}{r}3 \\
3 \\
11\end{array}$ & 5 & $\begin{array}{r}6 \\
6 \\
19\end{array}$ & $\begin{array}{l}4 \\
4 \\
9\end{array}$ & $\begin{array}{l}1 \\
1 \\
5\end{array}$ & $\begin{array}{l}4 \\
1 \\
5 \\
9\end{array}$ & $\begin{array}{r}1 \\
1 \\
12\end{array}$ & $\begin{array}{r}9 \\
9 \\
24\end{array}$ & $\begin{array}{r}1 \\
1 \\
12\end{array}$ & $\begin{array}{l}2 \\
2 \\
7\end{array}$ & $\begin{array}{l}1 \\
1 \\
6\end{array}$ & $\begin{array}{r}1 \\
1 \\
36\end{array}$ & $\begin{array}{r}4 \\
4 \\
29\end{array}$ & $\begin{array}{r}74 \\
3 \\
77 \\
343\end{array}$ \\
\hline Total & 109 & 23 & 66 & 14 & 5 & 25 & 13 & 6 & 14 & 13 & 33 & 13 & 9 & 7 & 37 & 33 & 420 \\
\hline P \% total & $21 \cdot 1$ & $4 \cdot 3$ & $22 \cdot 7$ & $21 \cdot 4$ & & $24 \cdot 0$ & $30 \cdot 8$ & $16 \cdot 7$ & $35 \cdot 7$ & $7 \cdot 7$ & $27 \cdot 3$ & $7 \cdot 7$ & $22 \cdot 2$ & $14 \cdot 3$ & $2 \cdot 7$ & $12 \cdot 1$ & $18 \cdot 3$ \\
\hline $\begin{array}{c}\text { Category } 1 \\
1-2 \\
1-3 \\
\mathbf{P} \\
1-1\end{array}$ & $\begin{array}{r}9 \\
9 \\
11\end{array}$ & 5 & $\begin{array}{r}2 \\
2 \\
11\end{array}$ & $\begin{array}{l}1 \\
1 \\
1\end{array}$ & 1 & $\begin{array}{l}4 \\
4 \\
3\end{array}$ & $\begin{array}{l}4 \\
4 \\
3\end{array}$ & $\begin{array}{l}1 \\
1 \\
2 \\
1\end{array}$ & 4 & 5 & $\begin{array}{r}8 \\
8 \\
10\end{array}$ & $\begin{array}{l}3 \\
3 \\
6\end{array}$ & $\begin{array}{l}1 \\
1 \\
1\end{array}$ & 2 & 4 & 14 & $\begin{array}{r}32 \\
2 \\
34 \\
82\end{array}$ \\
\hline Total & 20 & 5 & 13 & 2 & 1 & 7 & 7 & 3 & 4 & 5 & 18 & 9 & 2 & 2 & 4 & 14 & 116 \\
\hline P $\%$ total & $45 \cdot 0$ & & 15.4 & $50 \cdot 0$ & & $57 \cdot 1$ & $57 \cdot 1$ & $66 \cdot 7$ & & & $44 \cdot 4$ & $33 \cdot 3$ & $50 \cdot 0$ & & & & $29 \cdot 3$ \\
\hline $\begin{array}{c}\text { Category } 2 \\
2-3 \\
2-2\end{array}$ & $\begin{array}{r}3 \\
13\end{array}$ & 5 & $\begin{array}{l}3 \\
9\end{array}$ & 5 & 1 & $\begin{array}{l}3 \\
2\end{array}$ & & 1 & 1 & 3 & $\begin{array}{l}4 \\
8\end{array}$ & 1 & 1 & 2 & 14 & $\begin{array}{l}1 \\
12\end{array}$ & $\begin{array}{l}15 \\
77\end{array}$ \\
\hline Total & 16 & 5 & 12 & 5 & 1 & 5 & & 1 & 1 & 3 & 12 & 1 & 1 & 2 & 14 & 13 & 92 \\
\hline P $\%$ total & $18 \cdot 8$ & & 25.0 & & & 60.0 & & $100 \cdot 0$ & & & $33 \cdot 3$ & & & & & $7 \cdot 7$ & $16 \cdot 3$ \\
\hline $\begin{array}{c}\text { Category } 3 \\
3-3\end{array}$ & 21 & 3 & 8 & 1 & & & & 1 & 2 & & 7 & 4 & 2 & & 7 & 3 & 59 \\
\hline Total & 166 & 36 & 99 & 22 & 7 & 37 & 20 & 11 & 21 & 21 & 70 & 27 & 14 & 11 & 62 & 63 & 687 \\
\hline
\end{tabular}

C acceptable, B black, G grey, $\mathrm{W}$ white, $\mathrm{P}$ increase of category.

TABLE 4

EFFECT OF TECHNIQUE ON PROPORTIONS CHANGING THEIR CATEGORY (SINGLE FILMS)

\begin{tabular}{|c|c|c|c|c|c|c|c|c|c|c|c|c|c|c|c|c|c|}
\hline & \multicolumn{16}{|c|}{ Combination of Techniques } & \multirow{2}{*}{ Total } \\
\hline & $\mathrm{CC}$ & CB & CG & $\mathrm{CW}$ & BB & BC & BG & BW & GG & GB & GC & GW & WW & WB & WC & WG & \\
\hline $\begin{array}{l}\mathbf{P} \\
\mathbf{R} \\
\mathbf{P}-\mathbf{R} \\
\text { No change }\end{array}$ & $\begin{array}{r}41 \\
4 \\
37 \\
121\end{array}$ & $\begin{array}{r}8 \\
8 \\
28\end{array}$ & $\begin{array}{r}25 \\
1 \\
24 \\
73\end{array}$ & $\begin{array}{r}6 \\
6 \\
16\end{array}$ & $\begin{array}{r}1 \\
-1 \\
6\end{array}$ & $\begin{array}{l}16 \\
16 \\
21\end{array}$ & $\begin{array}{r}11 \\
11 \\
9\end{array}$ & $\begin{array}{l}6 \\
6 \\
5\end{array}$ & $\begin{array}{r}9 \\
2 \\
7 \\
10\end{array}$ & $\begin{array}{r}9 \\
1 \\
8 \\
11\end{array}$ & $\begin{array}{r}35 \\
1 \\
34 \\
34\end{array}$ & $\begin{array}{l}11 \\
11 \\
16\end{array}$ & $\begin{array}{r}3 \\
3 \\
11\end{array}$ & $\begin{array}{l}3 \\
1 \\
2 \\
7\end{array}$ & $\begin{array}{r}11 \\
2 \\
9 \\
49\end{array}$ & $\begin{array}{r}11 \\
6 \\
5 \\
46\end{array}$ & $\begin{array}{r}205 \\
19 \\
186 \\
463\end{array}$ \\
\hline Total & 166 & 36 & 99 & 22 & 7 & 37 & 20 & 11 & 21 & 21 & 70 & 27 & 14 & 11 & 62 & 63 & 687 \\
\hline P-R \% total & $22 \cdot 3$ & $22 \cdot 2$ & $24 \cdot 2$ & $27 \cdot 2$ & & $43 \cdot 2$ & 55.0 & $54 \cdot 5$ & $33 \cdot 3$ & $38 \cdot 1$ & $48 \cdot 6$ & $40 \cdot 7$ & $21 \cdot 4$ & $18 \cdot 2$ & 14.5 & 7.9 & $27 \cdot 1$ \\
\hline
\end{tabular}

C acceptable, $B$ black, $G$ grey, $W$ white, $P$ increase of category, $R$ decrease of category.

pneumoconiosis for coal-face workers in one pit into normal ones, and what is more important, it does the same for the sub-populations within the pits. The Figure shows that the fit is often very good, and that the deviations are not in one direction more than another. This normalizing transformation of the ordinary $x$-ray scale will be referred to as the $y$-scale.

The mathematical form of the transformation, namely $y=1.0167+0.2233 x^{2}-0.24 x^{-2}$

is not important; it was one of the simplest that could be found for which the three category boundaries $(x=1,2$, and 3 ) take the values $1,1 \cdot 85$, and 3 respectively; it also had to tend to infinity in the right direction as $x$ tends to zero or becomes large and positive. In later work (e.g. Rivers, Wise, King, and Nagelschmidt, 1960) the values of $y$ corresponding to the three category boundaries were changed to $1,1.9375$, and 3.222 ; the relative spacing is about the same, but the transformation simplifies to $y=1+0.25\left(x^{2}-x^{-2}\right)$

\section{Effect of Film Technique on Corresponding Distributions of Categories}

Each distribution, in the $y$ scale, is now described by two constants, the mean $m$, which is the same as the $50 \%$ point, and the standard deviation $s$. Both means and standard deviations were estimated 
TABLE 5

ANALYSIS OF THE FILMS TAKEN IN ONE PIT DURING ONE SURVEY; PERCENTAGES OF 0's, 1's, 2's, AND 3's FOR EACH KIND OF FILM, NUMBERS READ IN EACH CATEGORY (LAST ROW) AND NUMBERS OF C (GOOD OR ACCEPTABLE) B (BLACK), G (GREY), AND W (WHITE) FILMS (LAST COLUMN)

\begin{tabular}{|c|c|c|c|c|c|c|c|c|c|c|c|c|c|c|c|c|c|c|c|c|}
\hline \multirow{3}{*}{ Technique } & \multicolumn{5}{|c|}{ 1st Survey } & \multicolumn{5}{|c|}{ 2nd Survey } & \multicolumn{5}{|c|}{ 1st Survey } & \multicolumn{5}{|c|}{ 2nd Survey } \\
\hline & \multicolumn{4}{|c|}{ Category } & \multirow{2}{*}{$\begin{array}{l}\text { Total } \\
\text { No. }\end{array}$} & \multicolumn{4}{|c|}{ Category } & \multirow{2}{*}{$\begin{array}{l}\text { Total } \\
\text { No. }\end{array}$} & \multicolumn{4}{|c|}{ Category } & \multirow{2}{*}{$\begin{array}{c}\text { Total } \\
\text { No. }\end{array}$} & \multicolumn{4}{|c|}{ Category } & \multirow{2}{*}{$\begin{array}{l}\text { Total } \\
\text { No. }\end{array}$} \\
\hline & 0 & 1 & 2 & 3 & & 0 & 1 & 2 & 3 & & $\mathbf{0}$ & 1 & 2 & 3 & & 0 & 1 & 2 & 3 & \\
\hline $\begin{array}{l}\mathbf{C} \\
\mathbf{B} \\
\mathbf{G} \\
\mathbf{W}\end{array}$ & $\begin{array}{r}63.3 \\
100.0 \\
50.0 \\
52.2\end{array}$ & $\begin{array}{c}20 \cdot 0 \\
0 \\
50 \cdot 0 \\
4 \cdot 3\end{array}$ & $\begin{array}{c}11 \cdot 7 \\
0 \\
0 \\
39 \cdot 2\end{array}$ & $\begin{array}{l}5 \cdot 0 \\
0 \\
0 \\
4 \cdot 3\end{array}$ & $\begin{array}{c}\text { Pit } A \\
60 \\
3 \\
4 \\
23\end{array}$ & $\begin{array}{l}47.9 \\
71.4 \\
50 \cdot 0 \\
77.8\end{array}$ & $\begin{array}{l}16 \cdot 7 \\
14 \cdot 3 \\
16 \cdot 7 \\
11 \cdot 1\end{array}$ & $\begin{array}{r}29.1 \\
4.8 \\
25.0 \\
11.1\end{array}$ & $\begin{array}{l}6 \cdot 3 \\
9 \cdot 5 \\
8 \cdot 3 \\
0\end{array}$ & $\begin{array}{r}48 \\
21 \\
12 \\
9\end{array}$ & $\begin{array}{c}81.8 \\
\overline{5} \\
55 \cdot 6 \\
66.7\end{array}$ & $\begin{array}{c}9 \cdot 1 \\
\overline{16} \cdot 7 \\
0\end{array}$ & \begin{tabular}{c|}
0 \\
$\overline{11} \cdot 1$ \\
$33 \cdot 3$
\end{tabular} & $\begin{array}{c}9 \cdot 1 \\
\overline{16 \cdot 7} \\
0\end{array}$ & $\begin{array}{r}P i t \\
11 \\
0 \\
18 \\
3\end{array}$ & \begin{tabular}{|r}
$52 \cdot 6$ \\
$66 \cdot 7$ \\
$100 \cdot 0$ \\
$100 \cdot 0$
\end{tabular} & $\begin{array}{c}21 \cdot 1 \\
11 \cdot 1 \\
0 \\
0\end{array}$ & $\begin{array}{c}10 \cdot 5 \\
11 \cdot 1 \\
0 \\
0\end{array}$ & $\begin{array}{c}15 \cdot 8 \\
11 \cdot 1 \\
0 \\
0\end{array}$ & $\begin{array}{r}19 \\
9 \\
2 \\
2\end{array}$ \\
\hline Total & 55 & 15 & 16 & 4 & 90 & 51 & 14 & 19 & 6 & 90 & 21 & 4 & 3 & 4 & 32 & 20 & 5 & 3 & 4 & 32 \\
\hline $\begin{array}{l}\mathbf{C} \\
\mathbf{B} \\
\mathbf{G} \\
\mathbf{W}\end{array}$ & $\begin{array}{c}83 \cdot 3 \\
0 \\
75 \cdot 0 \\
66.7\end{array}$ & $\begin{array}{c}5.6 \\
0 \\
12.5 \\
16.6\end{array}$ & $\begin{array}{l}3 \cdot 7 \\
0 \\
0 \\
8 \cdot 4\end{array}$ & $\mid \begin{array}{r}7.4 \\
100 \cdot 0 \\
12.5 \\
8.3\end{array}$ & $\begin{array}{r}\text { Pit } C \\
54 \\
1 \\
8 \\
24\end{array}$ & $\begin{array}{c}73.7 \\
60 \cdot 0 \\
48.4 \\
0\end{array}$ & $\begin{array}{c}21 \cdot 0 \\
0 \\
22 \cdot 6 \\
0\end{array}$ & $\begin{array}{c}5.3 \\
40.0 \\
17 \cdot 7 \\
0\end{array}$ & $\mid \begin{array}{c}0 \\
0 \\
11 \cdot 3 \\
100 \cdot 0\end{array}$ & $\begin{array}{r}19 \\
5 \\
62 \\
1\end{array}$ & $\begin{array}{r}68 \cdot 6 \\
33 \cdot 3 \\
64 \cdot 3 \\
100 \cdot 0\end{array}$ & $\begin{array}{c}8.5 \\
33 \cdot 3 \\
19.0 \\
0\end{array}$ & $\begin{array}{c}14 \cdot 3 \\
33 \cdot 3 \\
14 \cdot 3 \\
0\end{array}$ & $\begin{array}{l}5 \cdot 6 \\
0 \\
2.4 \\
0\end{array}$ & $\begin{array}{r}\text { Pit } \\
35 \\
3 \\
42 \\
3\end{array}$ & \begin{tabular}{|l|}
31.7 \\
47.6 \\
50.0 \\
53.8
\end{tabular} & $\begin{array}{r}31.7 \\
20.1 \\
25.0 \\
7.7\end{array}$ & $\begin{array}{l}17 \cdot 1 \\
23.8 \\
25.0 \\
15.4\end{array}$ & $\begin{array}{c}19 \cdot 5 \\
9 \cdot 5 \\
0 \\
23 \cdot 1\end{array}$ & $\begin{array}{r}41 \\
21 \\
8 \\
13\end{array}$ \\
\hline Total & 67 & 8 & 4 & 8 & 87 & 47 & 18 & 14 & 8 & 87 & 55 & 12 & 12 & 4 & 83 & 34 & 20 & 16 & 13 & 83 \\
\hline $\begin{array}{l}\mathbf{C} \\
\mathbf{B} \\
\mathbf{G} \\
\mathbf{W}\end{array}$ & $\begin{array}{l}68.6 \\
71.4 \\
66.7 \\
72.4\end{array}$ & $\begin{array}{c}14 \cdot 3 \\
21 \cdot 5 \\
0 \\
10 \cdot 4\end{array}$ & $\begin{array}{c}14 \cdot 3 \\
7 \cdot 1 \\
0 \\
6 \cdot 9\end{array}$ & $\begin{array}{c}2 \cdot 9 \\
0 \\
33 \cdot 3 \\
10 \cdot 4\end{array}$ & $\begin{array}{c}\text { Pit } E \\
35 \\
14 \\
3 \\
29\end{array}$ & $\begin{array}{l}60.0 \\
75.0 \\
44.8 \\
33.3\end{array}$ & $\begin{array}{c}15.6 \\
25 \cdot 0 \\
13.8 \\
0\end{array}$ & $\begin{array}{c}17 \cdot 7 \\
0 \\
31 \cdot 1 \\
33 \cdot 3\end{array}$ & $\begin{array}{c}6.7 \\
0 \\
10.3 \\
33 \cdot 3\end{array}$ & $\begin{array}{r}45 \\
4 \\
29 \\
3\end{array}$ & $\begin{array}{l}69 \cdot 7 \\
67 \cdot 8 \\
63 \cdot 5 \\
50 \cdot 0\end{array}$ & $\begin{array}{r}7.9 \\
17.9 \\
15.9 \\
33.3\end{array}$ & $\begin{array}{r}9 \cdot 8 \\
14.3 \\
11 \cdot 1 \\
16.7\end{array}$ & $\begin{array}{l}12.6 \\
0 \\
9 \cdot 5 \\
0\end{array}$ & $\begin{array}{c}\text { Pit } F \\
51 \\
28 \\
63 \\
6\end{array}$ & $\begin{array}{l}36 \cdot 8 \\
33 \cdot 3 \\
40 \cdot 0 \\
47 \cdot 1\end{array}$ & $\begin{array}{l}22.1 \\
55.6 \\
20.0 \\
11.7\end{array}$ & $\begin{array}{l}19.0 \\
11.1 \\
30.0 \\
26.5\end{array}$ & $\begin{array}{c}22 \cdot 1 \\
0 \\
10 \cdot 0 \\
14 \cdot 7\end{array}$ & $\begin{array}{r}95 \\
9 \\
10 \\
34\end{array}$ \\
\hline Total & 57 & 11 & 8 & 5 & 81 & 44 & 12 & 18 & 7 & 81 & 97 & 21 & 17 & 13 & 148 & 58 & 32 & 31 & 27 & 148 \\
\hline $\begin{array}{l}\mathbf{C} \\
\mathbf{B} \\
\mathbf{G} \\
\mathbf{W}\end{array}$ & $\begin{array}{r}66.7 \\
77.8 \\
100.0 \\
54.2\end{array}$ & $\begin{array}{c}15.4 \\
5.6 \\
0 \\
20.8\end{array}$ & $\begin{array}{c}7 \cdot 7 \\
16 \cdot 7 \\
0 \\
16 \cdot 7\end{array}$ & \begin{tabular}{|c}
$10 \cdot 3$ \\
0 \\
0 \\
$8 \cdot 3$
\end{tabular} & $\begin{array}{c}\text { Pit } G \\
39 \\
18 \\
1 \\
24\end{array}$ & $\begin{array}{c}66 \cdot 7 \\
33 \cdot 3 \\
50 \cdot 0 \\
0\end{array}$ & $\begin{array}{c}5 \cdot 1 \\
33 \cdot 3 \\
18 \cdot 4 \\
0\end{array}$ & $\begin{array}{c}15 \cdot 4 \\
33 \cdot 3 \\
23.7 \\
0\end{array}$ & $\begin{array}{c}12 \cdot 8 \\
0 \\
7 \cdot 9 \\
100 \cdot 0\end{array}$ & $\begin{array}{r}39 \\
3 \\
38 \\
2\end{array}$ & $\begin{array}{c}57.9 \\
75.0 \\
5 \overline{5} \cdot 6\end{array}$ & $\begin{array}{c}5 \cdot 3 \\
12 \cdot 5 \\
- \\
7 \cdot 9\end{array}$ & $\begin{array}{c}13 \cdot 1 \\
22 \cdot 5 \\
\overline{-} \\
21 \cdot 2\end{array}$ & $\begin{array}{c}23 \cdot 7 \\
0 \\
\overline{18 \cdot 4}\end{array}$ & $\begin{array}{c}\text { Pit } H \\
\mathbf{3 8} \\
\mathbf{8} \\
\mathbf{0} \\
\mathbf{3 8}\end{array}$ & \begin{tabular}{|l|}
30.0 \\
66.7 \\
52.4 \\
33.3
\end{tabular} & $\begin{array}{c}16.7 \\
0 \\
19 \cdot 0 \\
11 \cdot 1\end{array}$ & $\begin{array}{l}13 \cdot 3 \\
33 \cdot 3 \\
16 \cdot 7 \\
33 \cdot 3\end{array}$ & $\begin{array}{c}40 \cdot 0 \\
0 \\
11.9 \\
22.2\end{array}$ & $\begin{array}{r}30 \\
3 \\
42 \\
9\end{array}$ \\
\hline Total & 54 & 12 & 10 & 6 & 82 & 46 & 10 & 16 & 10 & 82 & 48 & 6 & 14 & 16 & 84 & 36 & 14 & 15 & 19 & 84 \\
\hline
\end{tabular}

graphically to avoid extensive calculation; a rough correction for technique is all that can be expected on these data. Table 6 gives the values for $m$ and $s$ for every sub-population containing more than five readings.

The most consistent finding is that nearly all the sub-groups corresponding to poor films have smaller standard deviations than the corresponding ones for good films. The $s$ values for acceptable films, denoted by $s_{c}$, are the highest in all eight groups of sub-populations from the first survey. For the second survey the $s_{c}$ values are least in pits $\mathrm{A}, \mathrm{B}$, and $\mathrm{C}$; there is little difference in pits $\mathrm{D}$ and $\mathrm{E}$ but in pits $\mathrm{G}$ and $\mathrm{H}$ the $s_{c}$ values are still considerably greater than the other $s$ values.

The means $m$ of the transformed distributions are also affected by technique, but in a less regular and comprehensible way; in the first survey the distribution for $\mathrm{C}$ films had, on the average, the lowest means, but they were the highest for the second films. However, the graphical method of estimation tends to introduce a negative correlation between the two estimates, so that if $s$ is overestimated, $m$ must be underestimated. This is most serious when $m$ has to be estimated by extrapolation, that is when the proportion of films in category 0 is appreciably greater than $50 \%$. In the second survey this proportion is lower. Hence the results are compatible with the assumption that only the changes in standard deviation are real, and that the irregular changes of mean are artificial. Evidently too, there is a small but real negative correlation between the mean and standard deviation when the mean is large and negative, i.e. when there is really a high proportion of normal films.

\section{Interpretation}

There are three possible explanations of these findings. One is that the observers classifying pneumoconiosis are reluctant to read extreme categories on bad films. The second is that observers classifying radiographic technique are reluctant to classify films in categories 0 and 3 as of bad technique. The third is that the effect is one of random observer error which is increased in reading bad films and is acting upon an unusually shaped distribution, a U-shaped one or a bimodal one.

In ordinary bell-shaped distributions of a continuous variable, whether or not it is highly 

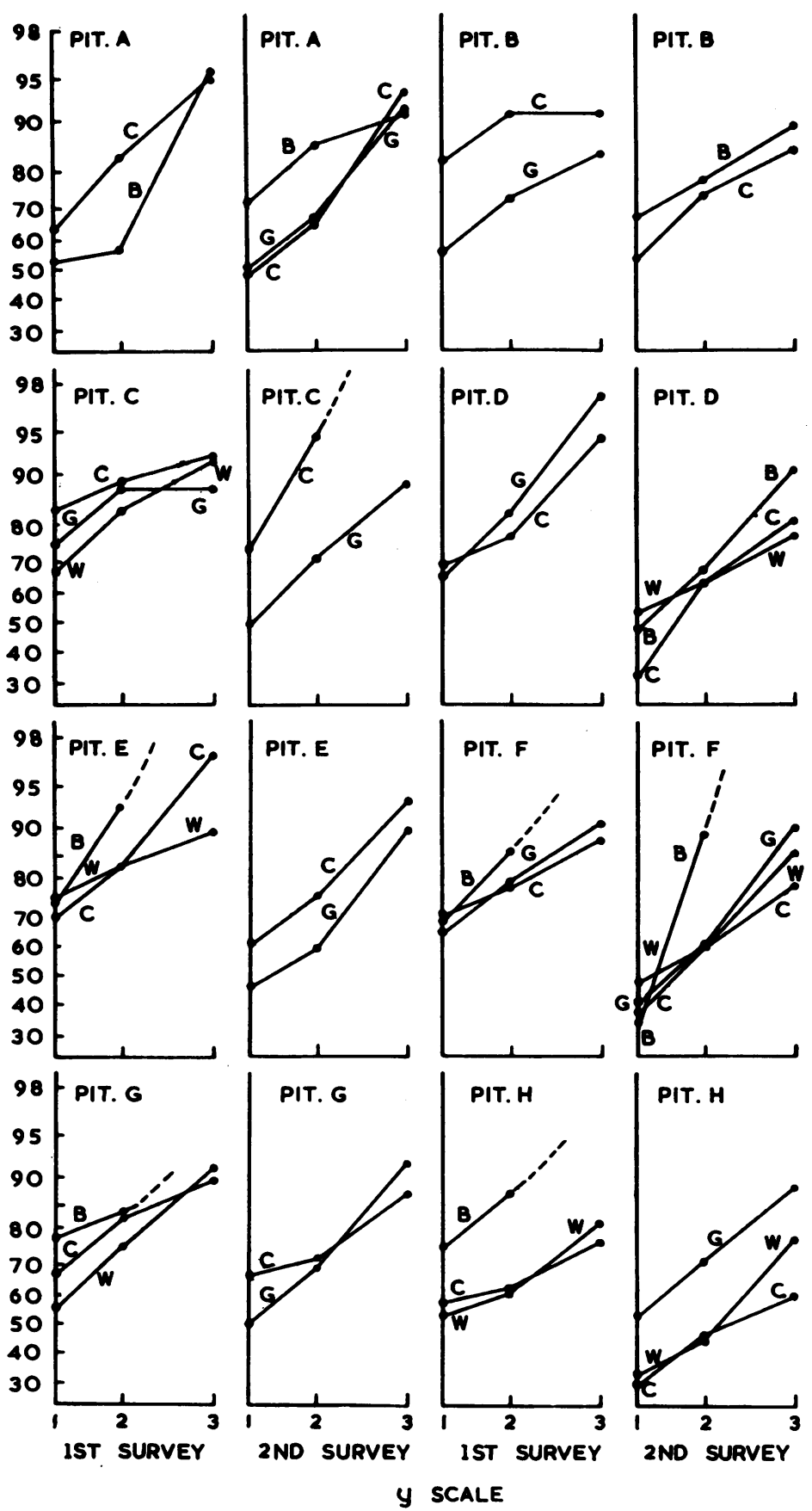

Figure.-Comparison of distributions of categories for films taken in each pit during the first and second surveys. C, acceptable films; B, black films; G, grey films; W, white films. Accumulated percentages plotted as in Fig. 8 (Wise and Oldham, 1963) on the $y$ (normalizing) scale, with the category boundaries, $x=1,2$, and 3 , shown at $y=1$, $1 \cdot 85$, and 3 respectively. grouped, random errors in the observations on this variable increase its observed standard deviation. But in these distributions of $x$-ray category, there are usually many more category 0 's than category 1's. We can consider the films for which the true $x$ values are not far from the 0 to 1 boundary; i.e. $x=1 \pm \epsilon$ when the observer error is quite likely to be greater than $\epsilon$. In most of the distributions considered more 0's (negative $\epsilon$ ) will be read as 1's than 1's (positive $\epsilon$ ) as 0 's simply because there are more 0's than 1's.

A related argument holds good at the other end of the continuum. The number of 2's and 3's is often about the same; sometimes, even, there are more 3's than 2's. There could also be a larger random error in reading a film whose true position on the continuum was 3.25 than one whose true position was $2 \cdot 75$. These two effects would, on balance, work inwards and increase the number of middle readings 1 and 2 at the expense of 'extreme' readings 0 and 3 . Thus an appreciable observer error would contract the observed distribution of categories, compared with the true one.

In the distribution listed in Table 6, there is less contraction of $s$ for the second surveys, and this is quite consistent with the idea that the excess of 0's over 1's has decreased from the first survey, while enough 1's have become 2's to compensate for the 2's that became 3's. In pit A, on the other hand, the distribution is $\mathrm{J}$-shaped and $s$ is not reduced for bad films in either survey.

It follows that among films from the same survey of the same pit, when the true distribution of categories is bimodal, the worst films are those with the smallest ratio of standard deviation to the corresponding one for good films. On this criterion the black 
TABLE 6

VALUES OF MEANS $m$ AND STANDARD DEVIATIONS $s$ OBTAINED GRAPHICALLY FROM ACCUMULATED PROBABILITIES CORRESPONDING TO THE OBSERVED DISTRIBUTIONS OF CATEGORIES OF TABLE 5, WITH BOUNDARIES BETWEEN CATEGORIES TRANSFORMED AS IN FIG. 1

\begin{tabular}{|c|c|c|c|c|c|c|c|c|c|}
\hline \multirow{2}{*}{ Pit } & \multirow{2}{*}{ Film } & \multicolumn{4}{|c|}{ 1st Films } & \multicolumn{4}{|c|}{ 2nd Films } \\
\hline & & $n$ & $m$ & $s$ & $s / s \mathrm{c}$ & $n$ & $m$ & $s$ & $s / s_{\mathrm{C}}$ \\
\hline $\mathbf{A}$ & $\begin{array}{l}\mathbf{C} \\
\mathbf{B} \\
\mathbf{G} \\
\mathbf{W}\end{array}$ & $\begin{array}{r}60 \\
3 \\
4 \\
23\end{array}$ & $\begin{array}{l}\frac{0.5}{7} \\
\frac{7}{1.0}\end{array}$ & $\frac{1 \cdot 46}{1 \cdot 25}$ & $\frac{1}{0 \cdot 86}$ & $\begin{array}{r}48 \\
21 \\
12 \\
9\end{array}$ & $\begin{array}{r}1.2 \\
-0.5 \\
1.0 \\
-0.1\end{array}$ & $\begin{array}{l}1.23 \\
2.34 \\
1.46 \\
1.52\end{array}$ & $\begin{array}{l}1.90 \\
1.90 \\
1.24\end{array}$ \\
\hline B & $\begin{array}{l}\mathbf{C} \\
\mathbf{B} \\
\mathbf{G} \\
\mathbf{W}\end{array}$ & $\begin{array}{r}11 \\
0 \\
18 \\
3\end{array}$ & $\begin{array}{c}-2.3 \\
\overline{0.6} \\
-\end{array}$ & $\begin{array}{c}3.70 \\
2.50 \\
-\end{array}$ & $\frac{1}{0.86}$ & $\begin{array}{r}19 \\
9 \\
2 \\
2\end{array}$ & $\begin{array}{r}0.7 \\
-0.1 \\
=\end{array}$ & $\begin{array}{c}2 \cdot 20 \\
2 \cdot 50 \\
=\end{array}$ & $\frac{1}{1 \cdot 14}$ \\
\hline C & $\begin{array}{l}\mathbf{C} \\
\mathbf{B} \\
\mathbf{G} \\
\mathbf{W}\end{array}$ & $\begin{array}{r}54 \\
1 \\
8 \\
24\end{array}$ & $\begin{array}{l}-3.0 \\
-\overline{1.0} \\
-0.1\end{array}$ & $\begin{array}{l}4 \cdot 17 \\
2 \cdot 95 \\
2 \cdot 16\end{array}$ & $\begin{array}{l}1 \\
0.70 \\
0.52\end{array}$ & $\begin{array}{r}19 \\
5 \\
62 \\
1\end{array}$ & $\begin{array}{l}\frac{0.6}{1.0} \\
-\end{array}$ & $\frac{0.79}{1.00}$ & $\frac{1}{1.27}$ \\
\hline D & $\begin{array}{l}\mathbf{C} \\
\mathbf{B} \\
\mathbf{G} \\
\mathbf{W}\end{array}$ & $\begin{array}{r}35 \\
3 \\
42 \\
3\end{array}$ & $\frac{1.0}{0.6}$ & $\frac{2 \cdot 25}{1 \cdot 28}$ & $\frac{1}{0.57}$ & $\begin{array}{r}41 \\
21 \\
8 \\
13\end{array}$ & $\begin{array}{l}1.6 \\
1.2 \\
1.0 \\
0.8\end{array}$ & $\begin{array}{l}1.40 \\
1.40 \\
1.26 \\
3.40\end{array}$ & $\begin{array}{l}1 \\
1.00 \\
0.90 \\
2.43\end{array}$ \\
\hline E & $\begin{array}{l}\mathbf{C} \\
\mathbf{B} \\
\mathbf{G} \\
\mathbf{W}\end{array}$ & $\begin{array}{r}35 \\
14 \\
3 \\
29\end{array}$ & $\begin{array}{r}0.4 \\
0.5 \\
-0.8\end{array}$ & $\begin{array}{l}1.40 \\
0.89 \\
2.97\end{array}$ & $\frac{1}{0.64}$ & $\begin{array}{r}45 \\
4 \\
29 \\
3\end{array}$ & $\frac{0 \cdot 7}{1 \cdot 3}$ & $\begin{array}{l}1.52 \\
1.49\end{array}$ & $\begin{array}{l}1 \\
0.98 \\
-\end{array}$ \\
\hline $\mathbf{F}$ & $\begin{array}{l}\mathbf{C} \\
\mathbf{B} \\
\mathbf{G} \\
\mathbf{W}\end{array}$ & $\begin{array}{r}51 \\
28 \\
63 \\
6\end{array}$ & $\begin{array}{r}-0.4 \\
0.3 \\
0.3 \\
1.0\end{array}$ & $\begin{array}{l}3.07 \\
1.23 \\
2.04 \\
0.88\end{array}$ & $\begin{array}{l}1 \\
0.40 \\
0.66 \\
0.29\end{array}$ & $\begin{array}{r}95 \\
9 \\
10 \\
34\end{array}$ & $\begin{array}{l}1.5 \\
1.2 \\
1.4 \\
1.2\end{array}$ & $\begin{array}{l}1.80 \\
0.51 \\
1.36 \\
1.82\end{array}$ & $\begin{array}{l}1 \\
0.28 \\
0.76 \\
1.01\end{array}$ \\
\hline $\mathbf{G}$ & $\begin{array}{l}\mathbf{C} \\
\mathbf{B} \\
\mathbf{G} \\
\mathbf{W}\end{array}$ & $\begin{array}{r}39 \\
18 \\
1 \\
24\end{array}$ & $\begin{array}{r}-0.3 \\
-0.7 \\
0.8\end{array}$ & $\begin{array}{l}2.45 \\
2.34 \\
1.58\end{array}$ & $\begin{array}{l}1 \\
0.96 \\
0.64\end{array}$ & $\begin{array}{r}39 \\
3 \\
38 \\
2\end{array}$ & $\begin{array}{r}-0.1 \\
-1.0 \\
\end{array}$ & $\begin{array}{c}2.80 \\
1.46 \\
-\end{array}$ & $\frac{1}{0.52}$ \\
\hline $\mathbf{H}$ & $\begin{array}{l}\mathbf{C} \\
\mathbf{B} \\
\mathbf{G} \\
\mathbf{W}\end{array}$ & $\begin{array}{r}38 \\
8 \\
0 \\
38\end{array}$ & $\begin{array}{r}0.5 \\
-0.2 \\
1 \cdot 1\end{array}$ & $\begin{array}{l}3 \cdot 59 \\
1 \cdot 73 \\
2 \cdot 31\end{array}$ & $\begin{array}{l}\frac{1}{0.48} \\
0 . \overline{64}\end{array}$ & $\begin{array}{r}30 \\
3 \\
42 \\
9\end{array}$ & $\begin{array}{l}2.3 \\
0.9 \\
1.8\end{array}$ & $\begin{array}{l}2.61 \\
1 \cdot 76 \\
1.68\end{array}$ & $\begin{array}{l}1 \\
0.67 \\
0.64\end{array}$ \\
\hline All Pits & $\begin{array}{l}\mathbf{C} \\
\mathbf{B} \\
\mathbf{G} \\
\mathbf{W}\end{array}$ & $\begin{array}{r}323 \\
68 \\
131 \\
144\end{array}$ & $\begin{array}{r}-0.38 \\
+0.02 \\
+0.36 \\
+0.45\end{array}$ & & & $\begin{array}{r}336 \\
60 \\
201 \\
65\end{array}$ & $\begin{array}{l}+1.15 \\
+0.41 \\
+1.04 \\
+1.01\end{array}$ & & \\
\hline \multirow{2}{*}{$\begin{array}{l}\text { 1st and } 2 \text { nd } \\
\text { films com- } \\
\text { bined }\end{array}$} & & & & & $n$ & $\bar{m}$ & & & \\
\hline & & & & $\begin{array}{l}\mathbf{C} \\
\mathbf{B} \\
\mathbf{G} \\
\mathbf{W}\end{array}$ & $\begin{array}{l}659 \\
128 \\
332 \\
209\end{array}$ & $\begin{array}{l}+0.403 \\
+0.202 \\
+0.773 \\
+0.624\end{array}$ & & & \\
\hline
\end{tabular}

Category 0 means $y<1$; category $1,1<y<1.85$, category $2,1.85<y<3$; category 3 , $y>3$. The last column gives the ratio of the standard deviations of the black, grey, and white films to that $\left(s_{\mathrm{c}}\right)$ for the corresponding good film. The values are tabulated only when $n>5$.

films are much worse than the white and grey ones, which are about equally bad (see also Table 7).

\section{How Distributions of Bad Films Were Adjusted for Analysing Progression}

The method of measuring badness provides at the same time the way of allowing for it. No attempt was made to adjust the $m$ values. For the $s$ values, separate adjustments were made for the black, grey, and white distributions $\left(s_{B}, s_{G}\right.$, and $\left.s_{W}\right)$. The first step was to find the mean ratios of the standard deviations for the black, grey, and white distributions to the one for the good films in the same pit and survey. In any such group of films containing both good ones and, for example, grey ones, a ratio $s_{G} / s_{C}$ can be obtained, and some of these ratios are based on many films of both kinds while others are deficient in one or both components. We devised a method of weighting the estimates of ratios. When there were $n_{C}$ good films in a particular group and $n_{P}$ poor films (either black, or grey, or white), the weighting factor $W\left(n_{C}, n_{P}\right)$ was chosen to be $W\left(n_{C}, n_{P}\right)=\left\{1 /\left(n_{C}-1\right)+1 /\left(n_{P}-1\right\}^{-1}\right.$.

This factor was used to multiply the values of $\log \left(s_{P} / s_{C}\right)$ in each sub-group. In this way weighted means were calculated (as ratios of the sum of the 
TABLE 7

SUM OF WEIGHTS AND WEIGHTED MEAN RATIOS OF STANDARD DEVIATIONS FOR THE BLACK (B), GREY (G), AND WHITE (W) FILMS TO THE CORRESPONDING SUB-POPULATIONS OF ACCEPTABLE (C) FILMS

\begin{tabular}{c|c|c|c}
\hline Film & Sum of Weights & Mean of $\log _{10} s / s_{\mathrm{c}}$ & $s_{\mathrm{c}} / s$ \\
\hline B & $84 \cdot 7$ & $\overline{1} \cdot 7160$ & 1.923 \\
G & 148.6 & $\overline{1} \cdot 8715$ & 1.344 \\
W & 126.1 & $\overline{1 \cdot 18848}$ & 1.304 \\
All & 359.4 & $\overline{1 \cdot 8395}$ & 1.447 \\
\hline
\end{tabular}

products to the sum of the weights) for $\log \left(s_{B} / s_{C}\right)$, $\log \left(s_{G} / s_{C}\right)$, and $\log \left(s_{W} / s_{C}\right)$.

The reason for this choice of weighting factor was as follows.

If $s_{p}$ and $s_{C}$ had been estimated analytically from large samples from normal distributions, the variance of $\log \left(s_{P} / s_{C}\right)$ would have been proportional to $1 / W\left(n_{C}, n_{P}\right)$. This seems a reasonable working rule in this case. It was only applied on sub-populations greater than five.

Table 7 gives the means of these logarithms, and the corresponding averaged ratios. Whenever the standard deviation $s$ for a distribution in the $y$-scale among either $\mathrm{B}, \mathrm{G}$, or $\mathrm{W}$ films was less than the corresponding distributions for $\mathrm{C}$ films it was multiplied by the appropriate mean factor; where $s$ was the larger, no change was made. Again no change was made on distributions of five or less. These adjustments for technique were thus on the small side, and the two ends of each distribution are affected more than its middle. Finally, for each pit and survey, the adjusted and unadjusted distributions were pooled.

\section{Conclusions}

It is perhaps unnecessary to say that these results do not necessarily hold good in general. But apart from the particular application to analysing radiological progression, they are of interest because they reveal such an unexpected effect of observer variation. For example, our findings seem to be quite incompatible with Ashford's (1959). In his model observer variation acts in the more usual way and increases the observed variance of a distribution of radiological categories. These are given, like ours, in a transformed scale that normalizes prevalence distributions in single pit populations. In this scale the points $x=1,2$, and 3 transform into 0,1 , and $2 \cdot 12$ respectively. Transformed values of fractional values of $x$ are not given and he avoids the need for them. If in this scale the prevalence distribution has true variance $\sigma^{2}$, then the observed one is increased to $\sigma^{2}+\delta^{2}$, where $\delta^{2}$ is the mean square of the observer's error when this had no bias, i.e. the mean of $\delta$ is zero. The larger this error is, the larger is the observed variance.
If it is true to assume that there is less observer error in the readings of our good films, our findings are just the other way round. This is unlikely to be because our normalizing scale is different, for the two scales do not differ very much in the relative spacings of the three category boundaries. It is possible, as already suggested, that the reduction of standard deviation is only found when the true distribution (in the $x$-ray category $(x)$ scale) is nearer to being bimodal or U-shaped. The distributions studied by Ashford are all J-shaped. Even for these his model may not be accurate at the upper end of the scale of abnormality; at the lower end the fit is good, but for groups of three readings containing at least one of category 2 there are systematic deviations of observed from expected frequencies (Fay and Ashford, 1960, Table 5).

A comparison with Liddell's study is interesting. He has a complete range of quality scores for greyness and for blackness in films. He compared the distributions of category readings of the best and worst films of the same miners. For six out of his eight readers there was very little difference in the readings on grey films, but six out of eight tended to read the black films too high, and one reader read them much too low. Even so the differences are not great. Our black films were more often read too low. Both sets of results can be explained if the random observer error of reading black films was large, and in Liddell's series was acting upon a Jshaped distribution of true abnormality (in the $x$ scale) and in ours upon a more nearly U-shaped one. The two sets of results complement one another if regarded in this way. It appears from his discussion that he doubts this, but it is not at all clear why. Mr. W. G. Clarke has pointed out to us one decided difference between the two series. Liddell's series probably contained many more very poor films. Our films when classed as "slightly black, grey, or white", would have been scored as acceptable by Liddell. About $5 \%$ in our series were "definitely" black, grey, or white, and about $50 \%$ in his.

This problem arose during the investigation of radiological progression in the surveys of the Pneumoconiosis 
Research Unit. One of us (M.E.W.) was in receipt of a personal grant from the Medical Research Council while this paper was being completed. The radiographs were read for film technique by Professor A. L. Cochrane, Dr. W. E. Miall, Mr. W. G. Clarke, and Dr. J. C. Gilson. We should like to thank Professor Cochrane in addition for providing the detailed analysis presented in Tables 2 , 3, and 4, and Dr. Gilson for helpful criticisms.

\section{REFERENCES}

Ashford, J. R. (1959). Applied Statistics, 8, 168

Fay, J. W. J., and Ashford, J. R. (1960). Brit. J. industr. Med., 17, 279.

Fletcher, C. M. and Oldham, P. D. (1949), ibid., 6, 168.

Kendall, M. G., and Stuart, A. (1958). The Advanced Theory of Statistics, Vol. 1, p. 18. Charles Griffin, London.

Liddell, F. D. K. (1961). Brit. J. industr. Med., 18, 165. Rivers, D., Wise, M. E., King, E. J., and Nagelschmidt, G. (1960).

Wise, M. E., and Öldham, P. D. (1963). ibid., 20, 124.

\section{THE JANUARY (1963) ISSUE}

The January (1963) issue contains the following papers:--

Asbestosis in Experimental Animals. J. C. WAGNER

The Fibrogenicity of Some Respirable Dusts Measured in Mice. D. RIVERS, T. G. MorRIS, and M. E. WISE, with the assistance of T. H. COOKE and W. H. ROBERTS

Aetiology and Pathology of Beat Knee. W. J. W. Sharrard

The Eye and Hydrogen Sulphide. R. W. R. BeAsLeY

Urinary Delta Amino-laevulinic Acid and Porphobilinogen in Lead-exposed Workers. A. J. de KretSER and H. A. WALDRON

Evaluation of Exposure to Nitrobenzene: Absorption of Nitrobenzene Vapour through Lungs and Excretion of $p$-Nitrophenol in Urine. J. Salmowa, J. Piotrowski, and U. NeuhorN

Fatal Addiction to Trichloroethylene. W. R. L. JAMES

Tetrachloroethane-A Survey. R. LoBo-MENDONÇA

A Vehicle for Use as an Audiology Unit. W. R. Lee, J. E. J. John, and F. Fowweather

Miscellanea

Toxicity of Tetramethyl Lead Solutions to Mice and Rabbits. N. Castellino, A. Rossi, and R. Molé Book Reviews

A number of copies are still available and may be obtained from the Publishing Manager, British Medical Association, Tavistock Square, W.C.1. price 18s. $6 d$. 